\title{
Architectural and Urban Communication in Social Identity: The Case Study of Agadir Morocco: From Colonial Preponderance to Renaissance Which Social Identity?
}

\author{
Amal Ben Attou \\ Laboratoire LARLANCO, Université IBN ZOHR, Agadir, Morocco
}

\begin{abstract}
This paper proposes the architectural communication as a socio-spatial identification, and a channel for the politico-patrimonial dialogue in a determined territory which is in this case the south Moroccan city of Agadir. By analyzing Agadir's urbanistic and architectural content thorough ages, we find ourselves involved in an enthralling and passionate debate concerning two important aspects. The first is the historical temporality of the city's architectural and urbanistic changes. In other words, it is the different architectural transformation related to the political transmutations that Agadir has witnessed since the Portugal settlement until the after earthquake of 1960. While the second is about the perception toward the architectural oeuvre deeply settled in the territory and the memory of the city's designers. This aspect is linked to the society's perception toward the architectural-urban transformations in their territory. In our paper, we are going to focus on two major architectural and urbanistic ages in the history of Agadir. The first period we are going to approach is the architectural and urbanistic features of Agadir during French settlement. The second period is Agadir's architectural renaissance after 1960s earthquakes. Since the core of our study is the architectural acts, it is definitely a matter of interpretation related to the philosophical, mental and ideological representation of the city’s architecture and urbanism either by those who artistically invented Agadir during colonialism or those who reinvented Agadir after 1960s earthquakes. Do urbanism and architecture represent for Agadir, a power, a doctrine or a savoir-faire? Can we affirm that Agadir's architecture is truly reflecting the image of its society? Is this society in itself immersed sufficiently in its architecture? Several hypotheses are possible in this research. Nevertheless, the fact that in this paper we use communication as a vehicle to establish a dialogue between arts, politics and socio-ideologic and territorial governance makes us recognize the different bridging relationships between the architectural action, the political and urbanistic content represented in the architectural expression. It also helps us to discover and analyze the ideologies that lead the architects during their conception. Finally, is this architecture which normally must represent the society in tempo-spatial territory admitted by the local citizens? All these are lines of research we are going to shed light on in this paper.
\end{abstract}

Keywords: territory, architecture, urbanism, communication, re-composition, identity

Amal Ben Attou, Ph.D. Student, Researcher, Architectural and Urban Communication, IBN ZOHR UNIVERSITY, LARLANCO laboratory. 


\section{Introduction}

The concept of architectural communication is a discipline through which we are going to analyze the thesis of our paper.

The era of colonialism represents in terms of architecture and urbanism the first real flourishment. During the French settlement Agadir and for the first time has owned an international reputation as a stop-over city for the air-mail connecting Europe to America before the famous Atlantic crossing. Indeed St-Exupéry symbolized Agadir's worldwide reach as the city of future and modernism. Under the French protectorate, Agadir's architecture has progressively taken the aspect of a miniaturized "NICE"; this comparison has been based on the city's characteristics such as its littoral. This specific point will insert Agadir in a touristic sphere in the future. However, this illustration is not utterly genuine, for the simple reason that the "KASBAH" is still existing, carrying implicitly and explicitly architectural traditions of an Arabo-Musulman medina renowned across Europe. From this stage, we ask ourselves if this double imaging is in fact a double architectural stamp or it is a medina splinted into European conglomeration? How can we communicate this double identity? The littoral or the mountain where can we localize the territorial stakes? The reconstruction of Agadir after the 1960s earthquake is it going to communicate the modernist vocation or is it going to put down the roots of a skillful society capable to reborn from its ashes? Finally, does Agadir's agglomeration today, throughout its architecture and urbanism identify either its citizens, national or international visitors? Is the local society able to communicate about their city's architectural and urban identity?

\section{The Architectural Appreciation Under the French Protectorate}

Under the protectorate, Agadir's urban morphology headed to architectural discontinuity and identity crisis. We notice this assessment through the double urban and architectural situation in this period. From one hand, defensive sites in which we find the working-class community: FOUNTY and AGADIR OUFELLA, invading the piedmont of IDA OUTANANE to a funnel opening to the coast. From the other hand, new European verdant districts that are senselessly converted and organized. The quarter of TALBORJT was the junction between two urbanistic and architectural styles. Nevertheless, between the two urban entities it was not a question of Arabo-European architectural transmutation; it was rather an economical strategy. We have to mention that the 50s was the era of important economic dynamism: fishery development, canning industry, agriculture and mining exploitation without taking into consideration the growth of tourism. For this reason, as much as Agadir inclined toward globalization as much as the architectural and urban contrast was increasing. In 1952, it was Michel Ecochard who set up a new urban planning compliance for Agadir. This new layout was designed for the reorganization of TALBORJT and ABATTOIR. The stated purpose was the blow out of the urban conglomeration as a result of post-war property speculation and disharmonious urban growth. Another implicit objective was the intention to decrease the original architectural identity which was magistrate as "Primitive" to switch to another architectural model the one of European center extension parallelly with the littoral. This colonial strategy makes us in front of two different trajectories and not in front of architectural and urban models transition. In view of its geographical situation, Agadir's harbor resumption along with the naval activities development integrated once again Agadir in an international commercial traffic. Bensergao aerodrome implementation for military purpose, decreed Sous as a military zone, once more this standardization is going to contribute to the amplification of the military staff positions. The French nobles was 
in need of entertainment space besides Paris gates ( $5 \mathrm{~h}$ from Agadir and $1 \mathrm{~h} 30 \mathrm{~min}$ from Casablanca). It is for this reason that Agadir was projected to become a seaside resort in Maréchal Lyautey's politic. To serve this aim Lyautey hired Henri Prost to consolidate and to erect the new born city of Agadir to a characterized coastal resort. It was at this time that the "Moroccan Nice" emerged. The urbanism designed by general Lyautey the creator of Modern Morocco, was a dual urbanism ${ }^{1}$ that is going to stamp the city forever by a sort of special apartheid. Initially the urbanism practiced was assimilating a form of doctrine, a supreme administration power. The utile Agadir was exclusively the harbor, the new designed city and by the littoral; the exact same thing was also experimented in Rabat, Casablanca and Kenitra. Such urbanism primary protected colonist's interests, then secured the European touristic presence. Behind the avowed modernity of Henri Prost (1912-1922) an architectural conservatism is hided. This observation is disseminated by the prefectural architecture. This urbanistic model was adapted to Agadir's touristic function (Gautier Hotel, Marhabat, Assaade, Provincial center). The monumental urbanism had as a principle mission to luxuriously address the modern cities, and also to keep them under the strict authority symbolized in architectural layouts. The second aspect of this decided urbanism is that the industrial districts "ABATTOIR" and the rest of indigenous areas, suffer from the lack of equipment, sanitation, and high ways. The life style and the physiognomy of the miniaturized touristic "Nice" expressed that Agadir is a modern outward city through organizing car races. Some sub-Saharan managers have not hesitated to qualify Agadir of that period as the Miami of North Africa. For Lyautey, it was not enough for Agadir to be a strategic military zone; for him it was more important to internalize the city by the resort in this way one projectile which is Agadir is going to guarantee a double objective. To more explain this idea, Lyautey aimed to both valorize the modernization imported from Europe and at the same time separate the new touristic city from the conglomeration of the two proletarian axes: ABATTOIR and ANZA. This is why he did not impose Moorish architecture as Casablanca, Rabat and Marrakech. He did not also express the need to keep vernacular symbols because it can oppose his vision and subsequently sentence monumental urbanism as an artificial urbanism.

This architectural "No man's Land" is going to create for the reconstruction architects the need to find picturesque Amazigh motifs, even Moorish symbols. Those architects preferred to decline through a multiple variation toward an architecture more or less tattooed traditionally in terms of art but based on a revisited modern technique. The industrial and touristic dynamics were the manpower attracting sources, this situation represented a threat for Lyautey's urban politic. While he always attempted to transmit athwart architecture the notion of the "Ville Vitrine" the vision of a new modern city using tourism to take a universal posture. For this reason, Michel Ecochard, under Lyautey's instructions, replaced Prost to instore a new popular strategy of the famous neighborhood unity applying the technique of building sanitary frames "Trames Sanitaire" (10X6M = $60 \mathrm{M}^{2}$ ) which allows Lyautey and his staff to anticipate the mass urbanism management. Obviously, the assigned objective was to restore balance in Agadir's urbanization and to avoid anarchic growth. The approved framework in 1952, had another mission that of separating the down town from the new extensions. The three aisles proposed for mass urbanization could not be organized in coherent manner. This urban planification caused the city's dissipation into three distinct parts: The down town near the littoral, industrial and insalubrious sectors around the Abattoir. At this period, the city started to enroll in critical urbanism. The

\footnotetext{
${ }^{1}$ It is about a sort of Clubbisaction of the urban life which is going to grantee for a long time the fragmentation of the city concerning the urban practice. For this aspect see Eric Charmes, 2011: La Ville Emiettée, Série la Ville en Débat, Edit. PUF, p. 288 (The Squandered City, City in Debate collection, Edit.PUF, p. 288).
} 
popular urbanization of Eric Labonne and Ecochard (1947-1953) raised a form of conflictual urbanism than a critical one. The neighborhood unity propelled by Ecochard is a theoretical model supposing the existence of immobile space and homogenic society. Nonetheless, neither the space was immobile nor the society was homogeneous. The harmony esteemed through the sanitary trames had in fact created tension. Thus, it appears that it is complicated to take hold of architectural objects because it is full of poetic images, experiences lived by society and through urbanism. It is about expressions regulated in time and space, it is not enough to be able to transpose an urban model in superiority or inferiority according to the society of origin. Risking artificiality, the approach of urban architecture through technicity, and housing sector or real-estate market is not always a sufficient solution for urban crisis. When we force autochthones lives, we instore a bursting even if we are opting for a modern project either architectural or urban. The cities are produced by both architectural and urban processes. The neighborhood unity, anticipated in Agadir in the end of the 40s and the beginning of the 50s shanty towns phenomenon.

\section{Earthquake: Architectural Rupture or a Chance for the City's Renaissance Through Architecture?}

From an architectural period to another, or from a simple architectural act to another, communication rises from a global dimension that opens horizons to ecology and ethics (Romano, 2001, 1990). Even if the ecology of communication is a recent science in Morocco, strictly in media, we can affirm that Agadir's reconstruction has promoted a global communication concerning both the seismic tragedy, and the reconstruction efforts. Agadir is a crises communication or crises management?

It is hard to decide. By closely observing that epoch and the breadthens of the dram, we can fittingly accord ourselves with Hervé Renaudin (2004) when he attests that the critique of communicational strategy stays a recurrent element (pp. 2-9). The tragedy's perception differs from logic to another and from a culture to another. Agadir's earthquake, then reconstruction is going despite the international mobilization efforts to bring out the rupture between society and institutions. It is also going to create tension between world's stakeholders that run developing countries. Who is going to build Agadir? Americans, Europeans or Moroccans? If Moroccans get the task, which logic are they going to follow? Which architectural and urbanistic trend are they going to adopt? The reconstruction project is it in itself sustainable? Which destiny? Which importance? Which actors?

This globalized rupture presents the dizziness between the needs of a damaged society and the way in which public power is going to manage it. A chess game is activated between seism and reconstruction in a crisis communicational sphere. Desires and logics are opposed. This opposition is represented by three intelligences. The first branch of those three streams is the one which seeks the continuity of the Ecochar's architectural and urbanistic conception, the second is the American model of Miami conceived by Bartholomew and the third and last one is the French urbanism practiced by Moroccans. The basic elements constituting the pivotal point of this chess game are: Modernism, orientalism and the reconstruction financial sources. Crises communication had also been omnipresent in the media by reinforcing the nobility attributed to the rebuilt city (Villarreal, 2007, pp. 2-10). This chess game's metaphors are widespread in modernist reflections and orientalist identity concerning the back and forth between Occidentalism and orientalism in terms of architecture (Libaret, 2005, pp. 2-16). Those powers are also manifested in the politic identification to Islam and to expressive Musulman art. They are also positioned visa à vis the international financing for 
developing countries. Even if the Moroccan team has owed the bet even if this team has produced collective work which was imposed as a natural necessity in which the whole city was embodied (Nadau, 1992, pp. 174-175). It is almost impossible to reconcile modernism to tradition in Agadir's architectural layout. Agadir has already chosen a touristic vocation before seism. The state in itself did not have the means to initiate a stylistic adventure concerning the city's architecture, that is to say that the reconstruction of Agadir could not initiate any type of architectural décor, miniatures or Islamic esthetics (Lucien, 1982, p. 2). The chess game ended to become an issue of providing shelter for mass population. This diagnostic sketched today refers us after 57 years of reconstruction to the chess game that becomes lead footed more and more by the fact that Agadir has been metropolises, and also by the fact of the urban spread of the "Grand Agadir". If today we consider Agadir's failure, we will notice that it is related to two major facts. The first, concerns the demographic urbanization emerging from rural areas. The second is the economic growth model based on the real estate bulimia in the 80s. These are two croisé phenomenons that have contributed to Agadir's urban collapse. The capitalist growth desired to insert Agadir in a closed economic system; consequently, instead of working in an incorporate strategic procedure, Agadir is under the pression of opportunism. The bourgeoisie which now constitutes the new rich population gets its benefits from estate speculation and illustrates it on the ground (Illigh District). However, in the 60s and 70s, there was a matching temptation to incorporate modernism in the Moroccan context. This project has been professed by Zevaco through the organized villas in the Swiss quarter in 1964, for which he received the Aghakhan trophy in 1980. Zevaco's modern architecture was adopting the patio style, economic habitations on the ground floor lightened from all angles, does this architecture represents renaissance?

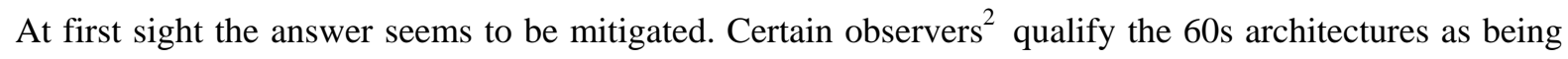
puritan. That is to say that the architectural oeuvre even if it is negligible it still represents an insurmountable challenge even contradictory: those of customers' requests bringing together a wrong identification of esthetic nostalgia and a will to produce images imported from different continents. It is a matter of evanescent cultural identity that hunted both the intellect and the work of the resigned architects to overcome the contradictions. Concerning the political power diffused in media spheres it is as well placed in opposition to the architects revindications. If politic stakeholders refuse the architectural style they do not come to term with the sense of this style. We also have the critique position of the architects who find themselves shaded of contradictions. For the most gifted designers such as Zevaco, the architectural language is poorly understood. Although, he highlighted transparence, consistence and puritan white, his dream raised from a utopia. We have also to precise that the utopia was that Agadir symbolizes the new Morocco. The Morocco that must be built or rebuilt normally should have included qualified tradition of outmoded quality.

South Mediterranean countries such as Morocco represent a sensitive object as much as an economic, social, cultural and professional field of interest. Their symbolic signification and their heritage are aspects of voluntary mobilization. The case of Agadir as an architectural project is a must to combine between functional and relational urbanism. The tradition vehiculated through vernacular is not only a cultural patrimony or a simple civilizational reference but also a model of urbanism; appreciated as an essential element for balance in the process of social, political and economic development. Despite the double penalty attributed to vernacular architecture, its impact on modern architectural production is obvious. This assessment allows us to confirm

${ }^{2}$ It is about architects such as Henri Tastemain, Elian Castelnau, Pierre Mas, Jean Challet, Louis Riou, and others. 
that the transition to modernism is significant. As the historians say "tradition is not inevitable and compulsory, old style or outdated it can always be recent” (Fathy, 1970, p. 310). We can understand that modernism does not imperatively mean that ideal life is a fruit of change. Thus, cities seem presenting an incredibly rich particularity of architectural patrimonies. The urban areas indicate deep syncretism that have generated common melting pot and a sort of connected world in which influence by context, exchange and borrowing styles are supplied by human circulation. However, some failures do exist: lack of reference points, symbolic deficit, excessive functional approach, regionalism obsession, deletion of tempo-socio-spacio process, intuitive speech production based only on hypothetic and subjective hints. In territories like Morocco, it is not hard to proceed in patrimonial reinterpretation to find identity or to adopt a morphologic approach in order to discover the organization laws. From the moment that urbanism and architecture are considered as luxury flows or as the only symbols of social promotion, this is displayed on the urban landscape in which we do not find any coherence or unity between tradition and modernism, there is no urban identification. Do modern architecture parameters exist in Agadir?

The answer is affirmative. Nevertheless, the fact that modernism is not a simple outcome of architects' personal conviction, makes this notion of "modernism" inserted in a political frame; yet, the fact of having a varied population of architects in the reconstruction site, public sensitization toward anti-seismic buildings, strictness in term of infrastructures elaboration, the inauguration of contracting authority and the quest of public edifice monumentality encouraged by public requests have made possible an architectural production able to be related to modern styles in terms of landscape, society and economy. We have to precise that Agadir's earthquake was an international tragedy in which solution finding was a Moroccan concern. The establishment of the high commissariat for reconstruction in 1962 assured legal means, land and financial mobilization (35 million DH) apart from the solidarity taxes created in 1960.

In 1960, Agadir's downtown is already achieved by Moroccan urbanistic team composed from Abdessamad Faraoui and Mourad Ben Embarek disciples of Ecochard, Louis Riou, Claude Verdugo, Elian Castelnau, writers and creators of the city's plan.

The communications concerning reconstruction have been strongly diffused by Ben Himma (health minister and future governor of Agadir). Other communicational manifestations have been initiated to promote Agadir's reconstruction and its architecture. "Casa Mémoire” is one of those events that aimed to be associated to the 50th anniversary of Agadir reconstruction by presenting its architectural history. Also, a co-memo ration of the same event will be organized by the city council on February 26th to 28th of every year. In addition to these two manifestations there is also Docomo-Maroc association and the regional council of architects of the south (CROAS), it organizes a series of workshops that are supposed to make objective assessment concerning the city's development in order to prepare for future challenges. Therefore the contemporaneous architectural production of Agadir had emerged as an adoption of a certain eclectic movement characterized by heterogeneous variety of modern and ancient styles. This is why we can affirm, today and without risk through the architectural monuments that Agadir's architectural modernity is at the same time a choice, an adaptation and an obligation. We have the post-seism Agadir which does not represent the complete start from starch as the majority of people think. This fact of rebuilding a city that still keeps some aspects of past created a certain necessity of adaptation to a new urbanistic strategy. We have the reconstruction of Agadir on the plain out of 
the prohibited zone of reconstruction in the north ${ }^{3}$, which have created a lot of constraints in terms of special rationalization and the infrastructures disposition. Between obligation and adaptation, some rebel architects opened the horizons to their creative mind in order to create independent edifices separated from any tradition or any religious architecture. It is the case of Zevaco and others who take refuge in the free rein, Amazigh motifs and the simple straight forms. However, this escape to modernity was not the general rule, some other architects used the style of vein domes (Central Market), other came back to the Greek classic theory ${ }^{4}$ of geometry. The emblematic image of Agadir's reconstruction ingrown the dream of a modern Morocco through the reconstruction architectural philosophy.

\section{Conclusion}

We can affirm without doubt that the architectural conceptualization of Agadir has been through three ages: pre-seismic age, during which architecture has taken a conflictual aspect with inversed trajectories. The second age confounded with reconstruction period until the middle of the 1980s. Agadir owes a lot to the transactional urban models of architectures. Such as Zevaco, Moroccan architects enrolled themselves in a restyled modernism inspired by the universal values experiences propelled by the Corbusier. However, the fact that concerning the recommended architectural elements, these same architects adopted a new property attitude through the arrangement, dimensions and materials, also their submission to the solar rule confirm their attachment to Arabo-Muslim architectures. We are here in front of a circular urbanistic and architectural model. A third age impacted by a commercial urbanism in which architecture is professed without architects. In the three ages, communication is struggling to face these constant changes. Indeed, the communicational deficit from which suffers Agadir's architecture is related to urban society. By default, by ignorance or by positioning, citizens are not informed, not comfortably placed in their architectural and patrimonial context. The article temps to fill this gap by bringing out the different architectural ages, the various architectural expressions in terms of conceptions, characteristics and ideologic affiliations. The objective is also the reconciliation between the architects and their background, their ideal, their tendencies and their limits. Far away from any virtual conceptualization, the article shows clearly the cross referencing of communication as a science and architecture in the urban scene, shedding lights on its crises and victory moments. Using different qualitative approaches, socio-spatial and tempo-geographical, it was a matter of proving how much a multiform communication platform is necessary to manage, orientate and sensitize about the patrimonial approach. Identity roots are not only on rocks but also in sprits. An effective communication map of architectural signatures can help the society to rediscover a reconstruction patrimony. It not enough to see and to make others see what is important is to make them feel. The need of a social and urban identification through architectural communication requires a social positioning. The purpose is to find what gathers us. What is a historical monument? How to identify ourselves according to this monument? How can we read and detect the architectural ages? How to verify the architectural information? How can we share it in the most optimal manner? It is these simple initiatives with deep impact that need to be established regarding the architectural communication.

\footnotetext{
${ }^{3}$ We have to mention that the famous geologic consulting office "Ambroggi” have condemned the ancient site and sketched a first plan for a secure place.

${ }^{4}$ For this theory, see Mazenod, 1976, op.cit. p. 579.
} 


\section{References}

Villarreal, B. P. (2007). L'agenda médiatique et la construction sociale de l'incertitude (Media diary and the social construction of uncertainty). Observatoire International des Crises, La Magazine de la Communication de Crise et Sensible Publications, $2-10$.

CABIN, P. (2010). Communication et Organisation (Communication and Organizations). In E. des Savoirs (Ed.), La Communication (Communication state of knowledge) (pp. 161-167). Paris: Sciences Humaines.

COSNIER, J. (2010). Empathie et communication, comprendre autrui et percevoir ses émotions, in Les Sciences de l'Information et de la Communication (Empathy and Communication, Understanding the Other and perceiving emotions, In Information and Communication Sciences) In E. des Savoirs (Ed.), La Communication (Communication state of knowledge) (pp. 149-154). Paris: Sciences Humaines.

CHARMES, E. (2011). La ville Emiettée, Série la ville en débat (The Squandered City, City in Debate collection, Edit. PUF) (p. 288). Paris: PUF.

HOFBAUER, L. (2010). Transfèrets de modèles architecturaux au Maroc, L’exemple de Jean-François Zévaco (1916-2003) (Architectural models transfer in Morocco, the exemple of Jean-François Zevaco (1916-2003)). Les Cahiers d'EMAM no 20, CITERS, Tours, 71-86.

GOLDBERG, J. (2008). La communication animale (Animal Communication). In E. des Savoirs (Ed.), La Communication (Communication state of knowledge) (pp. 33-41). Paris: Sciences Humaines.

Renaudin, H. (2004). Gestion de crise et réaction de l'organisation, la cellule de crise à la croisée des divergences (Crisis Management and the organizations reactions, crisis committee and divergence crossing). La Magazine de la Communication de Crise et Sensible Publications, 2-9.

HYMES, D. (1967). The Antropology of Communication. Report by Yves WINKIN, 2010. In E. des Savoirs (Ed.), La Communication (Communication state of knowledge) (pp. 33-41). Paris: Sciences Humaines.

Lucien, M. (1982). L'Islam et l'Art musulman (Islam and Musulment Art). d'Art L. Mazenod, (Ed.). Paris: Lucien Mazenod.

Libaert, T. (2005). Jeu d'échec et communication crise (Chess Game and Crisis Communication) (pp. 2-16). La Magazine de la Communication de Crise et Sensible Publications. Retrieved from www.tlibaert.info

Nadau, T. (1992). La reconstruction d'Agadir ou le destin de l'architecture moderne au Maroc (Agadir's reconstruction or the destiny of modern architecture in Morocco). Institut français d'Architecture, Architecture française Outre-mer, Collection Villes, Mardaga, 147-175.

Romano, V. (2001). Ecologia de la communication (Communication Ecology). Revue Labertino, (5), 1-8.

Romano, V. (1990). Ambivalencia de la comunication, por une ecología de los medinos (Ambivalence of communication for cities ecology). Revue Mensaje y Medios, (11), 74-82.

Fathy, H. (1970). Construire et vivre avec le people (Build and live with the nation). In J. Matineux (Ed.), Revue d'histoire critique (Journal of Critical History), 310. 